\title{
Influence of turbidity, food density and parasites on the ingestion and growth of larval rainbow smelt Osmerus mordax in an estuarine turbidity maximum*
}

\author{
Pascal Sirois, Julian J. Dodson** \\ Département de Biologie, Université Laval, Ste-Foy, Québec G1K 7P4, Canada
}

\begin{abstract}
We investigated the impact of turbidity, food density and parasites on ingestion and growth rates of rainbow smelt larvae Osmerus mordax. These 3 variables were selected because of their potential to substantially influence the feeding success, growth, and the subsequent survival of smelt larvae. A laboratory experiment was first performed to evaluate, in turbulent conditions, the combined effects of turbidity and food density on the ingestion and growth rates of smelt larvae. A field survey of the gut contents of larval smelt was conducted to directly estimate ingestion rates in 2 different regions of the St. Lawrence estuarine turbidity maximum (ETM) exhibiting different levels of turbidity but otherwise sharing similar environmental conditions. This study demonstrated that lower energetic costs are incurred by larvae that exploit similar feeding conditions at higher turbidities. Larval rainbow smelt in the ETM fed during the coincidence of daylight hours and flooding tide. Cestode parasites (genus Protocephalus) were found in the digestive tract of $38 \%$ of the larvae collected in the ETM. Parasitised larvae ingested half as much food as non-parasitised larvae. The decrease in feeding due to parasitism was associated with a reduced growth rate as suggested by the significantly lower standard lengths observed in parasitised larvae. Moreover, the size advantage of non-parasitised larvae is expected to be amplified because larger larvae ingest proportionally more food than smaller larvae. We suggest that the impact of parasitism on larval survival and subsequent recruitment in fishes merits far more attention than afforded to date.
\end{abstract}

KEY WORDS: Ingestion rate - Growth rate - Food density - Cestode parasite - Estuarine turbidity maximum $\cdot$ Rainbow smelt larvae

\section{INTRODUCTION}

Feeding success may affect the survival probability of fish larvae by reducing mortality due to starvation (Hjort 1914, Cushing 1975, Lasker 1978), and by improving growth and decreasing losses due to predation (Anderson 1988, Miller et al. 1988, Bailey \& Houde 1989, Cushing 1990). Small changes in mortality rates during early life stages may lead to significant variations in the year-class strength (Houde 1987). Therefore, knowledge of factors influencing the feeding of

\footnotetext{
- Contribution to the program of GIROQ (Groupe interuniversitaire de Recherches océanographiques du Québec) - Corresponding author. E-mail: julian.dodson@bio.ulaval.ca
}

fish larvae can contribute to a better understanding of the interannual variations observed in the recruitment of fish populations.

Larvae of a wide variety of fish species exploit estuaries as nursery areas. Estuaries such as that of the St. Lawrence are characterised by an estuarine turbidity maximum (ETM, also called maximum turbidity zone, transition zone or null zone) which is the dynamic frontal region where freshwater from the river first encounters saltwater from the sea. ETMs feature sharp gradients in abiotic and biotic factors such as salinity, temperature, turbidity, nutrient concentrations, and phytoplankton and zooplankton biomasses. Larvae of the anadromous rainbow smelt Osmerus mordax represent one of the principal components of the ich- 
thyoplankton community in the St. Lawrence Estuary (Able 1978), where they are principally concentrated within the ETM (Laprise \& Dodson 1989b). Many factors within the ETM may substantially influence the feeding, growth, and subsequent survival of smelt larvae.

Turbidity within ETMs is high and variable. The turbidity level at a fixed station in the St. Lawrence ETM can vary from 20 to more than 150 NTU within $1 \mathrm{~h}$ (Dodson et al. 1989). Many studies have been carried out to evaluate the effect of turbidity on feeding and growth rates of fish larvae (Swenson \& Matson 1976 Malmqvist \& Bronmark 1981, Johnston \& Wildish 1982 , Boehlert \& Morgan 1985, Breitburg 1988, Chesney 1989, Miner \& Stein 1993, Bristow \& Summerfelt 1994. Bristow et al. 1996). These studies have presented variable and conflicting conclusions on the impact of turbidity. It is difficult to compare these results because they have been conducted for very different purposes, including such divergent contexts as dredging and aquaculture. Three experimental studies have been conducted to evaluate the influence of the natural variations of turbidity observed in estuaries on the feeding and growth of estuarine fish larvae. Firstly, Breitburg (1988) suggested that an increase in turbidity caused a decrease in food consumption by striped bass larvae due to a reduction of the search volume. On the other hand, Boehlert \& Morgan (1985) found that turbidity enhanced feeding success of Pacific herring larvae and suggested that the increase in contrast between prey and the background environment was responsible for the observed effect. Finally, Chesney (1989) reported that turbidity varying from 40 to 130 NTU had no effect on ingestion and growth rates of striped bass larvae, but observed lower growth rate in total absence of turbidity (0 NTU). The low light intensity level in the study of Breitburg (1988) may explain the negative impact of turbidity (Miner \& Stein 1993). Nevertheless, the influence of turbidity on feeding success of larval fish remains unclear Even if food availability plays a central role in assessing the impact of turbidity, little attention has been given to the combined effects of turbidity and food density on the ingestion and growth rates of larval fish. In addition, the influence of turbidity has never been evaluated in the wild.

Concentrations of food for larval smelt can vary from 4 to 428 organisms $1^{-1}$ within the St. Lawrence ETM (Sirois \& Dodson unpubl.). In laboratory conditions, it is weil established that an increase in food density enhances larval ingestion and growth rates (e.g. Wyatt 1972, Werner \& Blaxter 1980, Houde \& Schekter 1981 , Kiørboe \& Munk 1986). However, under field conditions, estimates of ingestion rates may not be dependent on food density, but rather be related to the rate of contact between larvae and their prey (Mackenzie et al. 1990). Encounter rate between fish larvae and their prey can be influenced by food density (or the seasonal production of planktonic prey), and by physical factors such as turbulence (Rothschild \& Osborn 1988). Therefore, for a given level of food density, an augmentation of turbulence enhances the encounter rate between fish larvae and their prey. On the other hand, in the presence of similar turbulent conditions, an increase in food density also improves the encounter rate between fish larvae and their prey.

Cestode and trematode parasites have been observed in the digestive tract of smelt larvae in the St. Lawrence Estuary (Courtois \& Dodson 1986, Dauvin \& Dodson 1990). Many investigators noted the presence of a cestode (Rosenthal 1967, Marak 1974, Govoni 1983. Heath \& Nicoll 1991) or a trematode (Lebour 1918, Mackenzie 1974, Yamashita 1979, Govoni 1983, Heath \& Nicoll 1991) in the stomach and intestine of larval fishes from various taxa. However, little attention has been given to the influence of the presence of parasites in the gut on the feeding, growth, and survival of fish larvae. Heath \& Nicoll (1991) observed a significantly lower feeding incidence in larval herring infected by a cestode in the North Sea. Parasites in the gut can compete for nutrients and for space in the digestive tract (Rosenthal 1967), and can cause corporal damage to the larvae (Yamashita 1979). Parasites will unlikely kill their host directly, but by reducing growth through effects on feeding, they can have a significant impact on survival (May 1983, Minchella \& Scott 1991).

The principal objective of this study is to assess the influence of turbidity, food density and parasites on ingestion and growth rates of larval rainbow smelt Osmerus mordax. These 3 variables were considered as having a substantial impact on the feeding, growth, and subsequent survival of smelt larvae in the St. Lawrence ETM. Firstly, a laboratory experiment was conducted to evaluate, in turbulent conditions, the combined effects of turbidity and food density on the ingestion and growth rates of smelt larvae. Secondly, a field survey of the gut contents of larval smelt was conducted to directly estimate ingestion rates in 2 different regions of the St. Lawrence ETM exhibiting different levels of turbidity but otherwise sharing similar environmental conditions.

\section{MATERIALS AND METHODS}

Laboratory experiment. A laboratory experiment was conducted by rearing smelt larvae (aged 8 to $19 \mathrm{~d}$ ) in sixteen 601 tanks using a combination of 4 levels of food density $\left(5,50,500,3500\right.$ organisms $\left.l^{-1}\right)$ and 4 levels of turbidity $(5,30,55,80$ nephelometric turbidity units, NTU). Such levels of turbidity are typical of the 
St. Lawrence Estuary (Dodson et al. 1989). The experiment was conducted at an aquaculture station (Station aquicole de l'INRS, Pointe-au-père, QC, Canada) located $200 \mathrm{~km}$ downstream of the rainbow smelt nursery area on the St. Lawrence Estuary. At this station, natural saltwater was available from a $10 \mathrm{~m}$ deep pumping station and freshwater was provided from the municipal reserve and filtered on activated charcoal. Food density was controlled by adding live wild-caught zooplankton to the tanks. Each day of the experiment, zooplankton was concentrated in an $80 \mathrm{l}$ basin ( $63 \mu \mathrm{m}$ mesh sides) using a pumping system from the shore of the estuary. Food was composed of marine plankton, mostly copepod nauplii ( $80 \%)$, polychaete larvae $(11 \%)$, bivalve larvae $(5 \%)$ and some copepodite and adult stages of Acartia sp. The food species composition was somewhat different from what larval smelt encounter in the ETM, but copepod nauplii constitute a major food item for the larvae of many young marine fishes. Turbidity was adjusted in the tanks with natural estuarine sediment collected at low tide from mudflats along the south shore of the St. Lawrence ETM.

Fertilised smelt eggs were obtained from a governmental incubator (Ministère de l'Environnement et de la Faune du Québec) located on a small creek at Beaumont on the south shore of the St. Lawrence Estuary. Rainbow smelt spawning in the tributaries on the south shore constitute one of the 2 genetically distinct sympatric populations identified in the St. Lawrence Estuary (Bernatchez \& Martin 1996). Recent work suggests that larvae of the south shore population occupy the shallow bays of the estuary's south shore within the ETM, while larvae of the north shore population exploit the pelagic environment within the ETM (Pigeon et al. 1998, Lecomte \& Dodson unpubl. data). As both populations inhabit the St. Lawrence ETM during their early life, there is no reason to believe that they will respond differently to turbidity, food density and parasitism.

Hatching occurred during the night after delivery to the aquaculture station (25 May 1995) and newly hatched larvae were reared for a $6 \mathrm{~d}$ period in four $60 \mathrm{l}$ tanks (ca 1000 larvae $\operatorname{tank}^{-1}$ ) until the resorption of the yolk-sac. During this period, environmental conditions in the tanks were constant for all larvae (water temperature $=14.5$ to $15.7^{\circ} \mathrm{C}$, salinity $=0 \mathrm{psu}$, turbidity $=0$ to $5 \mathrm{NTU}$, food density $=300 \mathrm{l}^{-1}$, photoperiod $=14: 10 \mathrm{~h}$ $\mathrm{L}: \mathrm{D}$ light intensity at surface $=7.7 \mu \mathrm{E} \mathrm{m}^{-2} \mathrm{~s}^{-1}$ ). On the 7 th day after hatching, 150 larvae were transferred to each of the 16 experimental tanks and allowed $1 \mathrm{~d}$ to acclimate to their new environment. Each experimental tank represented a combination of a level of food density and a level of turbidity and was equipped with a moving plastic blade at the bottom in order to simulate turbulence and to maintain sediment in suspen- sion. On each day of the $12 \mathrm{~d}$ experiment ( 8 to $19 \mathrm{~d}$ after hatching), turbidity and food density were monitored and adjusted to the nominal value. Other environmental conditions varied little among tanks and represented similar conditions to those a larva could encounter in its natural nursery area at that time of year (water temperature $=15.4$ to $17.5^{\circ} \mathrm{C}$, salinity $=3$ to 4 psu, photoperiod $=14: 10 \mathrm{~h} \mathrm{~L}: \mathrm{D}$, light intensity at surface $\left.=15.1 \mu \mathrm{E} \mathrm{m}^{-2} \mathrm{~s}^{-1}\right)$. After $12 \mathrm{~d}$ of experiment, surviving larvae were collected, preserved in 95\% ethanol and 15 larvae $\operatorname{tank}^{-1}$ were chosen randomly and measured using a camera connected to an image analysis system. No correction for larval shrinkage was necessary (Sirois et al. 1998).

Absolute growth rates (in $\mathrm{mm} \mathrm{d}^{-1}$ ) were estimated using the measured standard length at capture and the back-calculated length at the beginning of the experiment determined by the analysis of otolith microstructure. Details on removal, preparation and reading of otoliths of smelt larvae are given in Sirois et al. (1998). Length back-calculations were performed for each day of the experiment using the time-varying growth (TVG) procedure (Sirois et al. 1998).

Food ingestion in the tanks was estimated by an indirect procedure assuming that all the zooplankton added to the tank was eaten by smelt larvae. Thus, the number of prey items eaten by larvae was calculated on each day in each tank by taking into account the number of zooplankton added to maintain the nominal food density and the number of larvae present in the tank on that day. An exponential mortality rate was assumed between the abundance of larvae at the beginning and at the end of the experiment to determine the number of fish present in each tank on each day. Exponential mortality rate is typical of the early life-history stages of fishes (Campana \& Jones 1992).

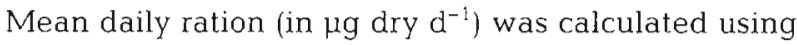
a dry weight of $0.26 \mu \mathrm{g}$ prey item ${ }^{-1}$ (based on the dry weight of a copepod nauplii of Acartia sp., Mauchline 1998). To compare food ingestion among tanks, standardised daily rations (in $\mu \mathrm{g}$ dry $[100 \mu \mathrm{g} \text { dry }]^{-1} \mathrm{~d}^{-1}$ ) were computed as the ratio of the mean daily ration (in $\mu \mathrm{g}$ dry $\mathrm{d}^{-1}$ ) on the mean larval weight (in $100 \mu \mathrm{g}$ dry) on that day. Weights of larval smelt ( $W_{\mathrm{L}}$ in $\mu \mathrm{g}$ dry) were estimated from back-calculated lengths ( $L$ in $\mathrm{mm}$ ) using a length-weight relationship $\left(W_{\mathrm{L}}=0.2606 \mathrm{~L}^{2.9123}\right.$, $\mathrm{n}=30, \mathrm{r}^{2}=0.967, \mathrm{p}<0.0001$ ). Total ingestion (in $\mu$ g dry $\left[100 \mu \mathrm{g} \mathrm{dry}^{-1}\right.$ ) represented the sum of the 12 standardised daily rations measured during the experiment.

For statistical analysis, the 2 lower levels of turbidity ( 5 and $30 \mathrm{NTU}$ ) were combined into the same treatment to procure replicates. The same procedure was done for higher turbidities (55 and 80 NTU). Higher levels of turbidity are typically observed within the St. Lawrence ETM, whereas lower turbidities are more 


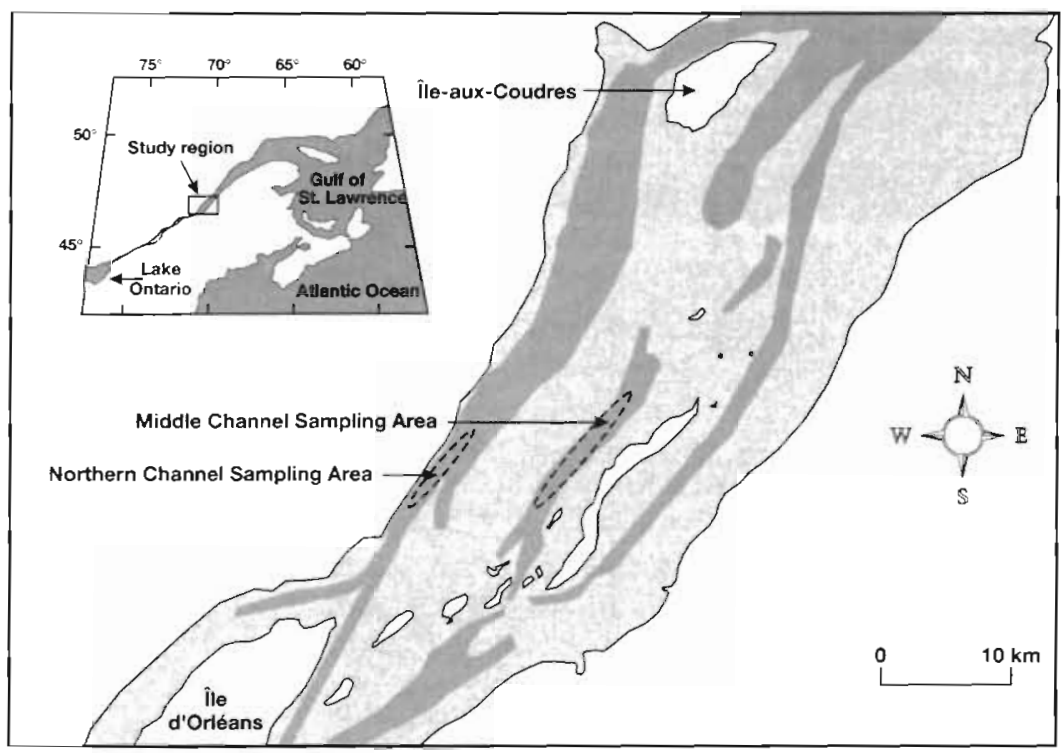

Fig. 1. St. Lawrence ETM and location of the stations sampled in July 1996 in the Middle Channel and in the Northern Channel. Dark shading marks the regions deeper than $10 \mathrm{~m}$

representative of the region downstream of the ETM. Two-way ANOVA (4 levels of food density and 2 levels of turbidity) was used to compare absolute growth rate, total ingestion, mortality rate and initial back-calculated length in the tanks.

Field survey. The St. Lawrence ETM is located between 50 and $90 \mathrm{~km}$ downstream of Québec City (Canada) and encompasses the salinity range 0 to 10 psu (between Île d'Orléans and lle-aux-Coudres in Fig 1). The ETM is a macrotidal system receiving an annual mean discharge of $12600 \mathrm{~m}^{3} \mathrm{~s}^{-1}$ from the river. This region is characterised by sediment resuspension and the circulation is dominated by semi-diurnal lunar tides ranging from 4 to $6 \mathrm{~m}$ in height.

Larval rainbow smelt were collected during a $12 \mathrm{~h}$ tidal cycle in the St. Lawrence ETM on 4 occasions in 1996: 22 July (09:30 to 20:00 h), $23-24$ July (21:30 to $09: 30 \mathrm{~h}), 29-30$ July $(18: 30$ to $06: 30 \mathrm{~h})$, and $31 \mathrm{July}$ (8:00 to $18: 30 \mathrm{~h})$. The first 2 sampling series were conducted in the Middle Channel of the ETM, while the 2 others were conducted in the Northern Channel (Fig. 1). Fixed anchor stations were not occupied but rather the sampling boat followed the 0 to 2 psu salinity stratum as measured in surface waters. As the water column was well mixed, surface salinities were indicative of bottom salinities. The water column was sampled every $1.5 \mathrm{~h}$. On each occasion, surface $(0$ to $5 \mathrm{~m})$ and bottom (12 to $20 \mathrm{~m}$ ) layers were sampled successively using a Tucker trawl $(1.09 \times 1.19 \mathrm{~m})$ equipped with an opening-closing device and a $0.5 \mathrm{~m}$ standard plankton net (500 $\mu \mathrm{m}$ mesh). The sampling of the surface and the bottom layers permitted the capture of lar- val smelt at each station during their active tidal vertical migration (Laprise \& Dodson 1989a). A General Oceanic flowmeter was fitted at the mouth of the gear to measure filtration rate. Each tow lasted ca $10 \mathrm{~min}$ and filtered on average $800 \mathrm{~m}^{3}$ of water. Due to bad weather, samples on 24 July at 00:30 h (bottom layer) and at 03:00 h were not obtained.

Salinity and temperature profiles were monitored at each station using a Seabird seacat profiler. Turbidity was measured in water samples obtained with Niskin bottles at each depth layer using a Hach turbidity meter (model 2100A). In addition, zooplankton concentrations were estimated on 4 sampling occasions in each channel using 2 vertical tows of a $0.5 \mathrm{~m}$ standard net ( $64 \mu \mathrm{m}$ mesh) from the bottom to the surface and from $5 \mathrm{~m}$ to the surface.

All sampled larvae were anaesthetised in a carbon dioxide solution to prevent regurgitation of gut contents and preserved in $4 \%$ buffered formaldehyde. In the laboratory, between 3 and 15 larvae (mostly 15) were selected from each sample and were measured using a camera connected to an image analysis system. A total of 905 smelt larvae were analysed under a dissecting microscope. Each prey item observed in the digestive tract was identified and measured (length and width) using an ocular micrometer. The presence of parasites in the digestive tract was noted and identified to class (cestode and trematode). Prey volume was calculated assuming a spherical shape for copepod eggs, an ellipsoid for cladocera, rotifera and bivalve larvae, a half-cylinder for copepod nauplii, and a cylinder for other items and unidentified material. Gut volume represented the total volume of all prey in the gut. Prey weight was calculated from length-weight relationships found in the literature (Table 1). Total weight of food ingested ( $W$ in $\mu \mathrm{g}$ dry) was the summed weight of all prey in the digestive tract.

The Elliott \& Persson (1978) model allows direct estimation of fish daily ingestion rate in the field. This model required measuring variations in digestive tract contents over a $24 \mathrm{~h}$ period and estimating a value for the evacuation rate occurring during the same period. To estimate daily ingestion rates of smelt larvae in this study, the two $12 \mathrm{~h}$ sampling series in each channel were combined to represent a $24 \mathrm{~h}$ feeding cycle. Daily ingestion rate $\left(C_{24}\right.$ in $\mu \mathrm{g}$ dry [100 $\mu \mathrm{g}$ dry $]^{-1} \mathrm{~d}^{-1}$ ) as estimated by the Elliott \& Persson model was: 
Table 1. Number, size range, and biomass conversion equations for prey items measured in the digestive tract of smelt larvae $D W$ is dry weight in $\mu \mathrm{g}, L$ is length in $\mathrm{mm}, F W$ is fresh weight in $\mu \mathrm{g}$ and $V$ is volume in $\mathrm{mm}^{3}$

\begin{tabular}{|c|c|c|c|c|}
\hline Taxon & $\mathrm{n}$ & $\begin{array}{l}\text { Size range } \\
(\mathrm{mm})\end{array}$ & Biomass conversion & Source \\
\hline Eurytemora affinis egg & 14114 & $0.075-0.100$ & $D W=0.13 \mu \mathrm{g}$ & Heinle \& Flemer (1975) \\
\hline Bosmina longirostris & 9228 & $0.251-0.502$ & $D W=17.737 L^{2.229}$ & Culver et al. (1985) \\
\hline Eurytemora affinis & 5830 & $0.377-0.979$ & $D W=10^{2.088 L-0.859}$ & Burkill \& Kendall (1982) \\
\hline Copepod nauplii & 358 & $0.151-0.377$ & $D W=3.009 L^{1706}$ & Culver et al. (1985) \\
\hline Copepod & 183 & $0.251-0.929$ & $D W=7.047 L^{2.399}$ & Bottrell et al. (1976) \\
\hline Gammarus sp. & 72 & $0.907-2.284$ & $D W=9.616 L^{2.604}$ & Pöckl (1992) \\
\hline Daphnia sp. & 29 & $0.552-2.585$ & $D W=4.967 L^{2.84}$ & Dumont et al. (1975) \\
\hline Mysid & 27 & $0.703-5.196$ & $D W=6.605 L^{2.57}$ & $\begin{array}{l}\text { Chigbu \& Sibley (1996) } \\
\text { See also Richards \& Riley (1967) }\end{array}$ \\
\hline $\begin{array}{l}\text { Dreissana polymorpha } \\
\text { larvae }\end{array}$ & 10 & $0.151-0.226$ & $\begin{array}{l}F W=37 L^{2}-2.636 L+0.058207 \\
D W=0.5 F W\end{array}$ & $\begin{array}{l}\text { Hillbricht-Ilkowska \& Stanczykowska (1969) } \\
\text { Sprung (1993) }\end{array}$ \\
\hline Diptera larvae & 2 & $2.560-2.836$ & $D W=5.402 L^{243}$ & Smock $(1980)$ \\
\hline Rotifera & 1 & 0.301 & $D W=0.32 \mu \mathrm{g}$ & Dumont et al. (1975) \\
\hline Unidentified material & & & $D W=109.08 V^{0.9591}$ & This study \\
\hline
\end{tabular}

$$
C_{24}=\sum_{i=1}^{K} C_{T i}
$$

where $C_{T i}$ (in $\mu \mathrm{g}$ dry $[100 \mu \mathrm{g} \text { dry }]^{-1}$ ) was the quantity of food ingested by fish during a time interval $i$, and $K$ is the number of intervals per day. $C_{T i}$ was computed as:

$$
C_{r i}=\frac{\left(F_{t+1}-F_{t} \mathrm{e}^{-R T}\right) R T}{1-\mathrm{e}^{-R T}}
$$

where $F_{t}$ and $F_{t+1}$ were, respectively, the geometric mean of the gut fullness of smelt larvae at the beginning and at the end of the interval. $R$ (in $\mathrm{h}^{-1}$ ) was the exponential evacuation rate and $T$ was the length of the interval in hours. Gut fullness ( $F$ in $\mu \mathrm{g}$ dry [100 $\mu \mathrm{g}$ dry $]^{-1}$ ) of each larva was calculated as:

$$
F=\frac{100 W}{W_{\mathrm{L}}}
$$

where $W_{\mathrm{L}}$ is the larval weight in $\mu \mathrm{g}$ estimated using the length-weight relationship of smelt larvae (see above, 'Materials and methods: Laboratory experiment). Evacuation rate $(R)$ was calculated using the interval where the slope of food decline in the digestive tract was maximal during the daily survey (Boisclair \& Leggett 1985, Boisclair \& Marchand 1993, Héroux \& Magnan 1996):

$$
R=\frac{\ln F_{t+1}-\ln F_{t}}{T}
$$

An estimate of the daily ingestion rate in each channel was first computed using all of the larvae analysed at each station (surface and bottom layer pooled). Afterward, daily ingestion rates were calculated in both channels for sub-groups of larvae defined by their infection status (parasitised vs non-parasitised larvae), depths of capture (surface layer vs bottom layer larvae), or size classes (small vs large larvae). The latter were determined from the median lengths observed in each channel (19.265 $\mathrm{mm}$ in the Middle Channel and $20.990 \mathrm{~mm}$ in the Northern Channel).

Contingency table analysis was used to compare proportions of parasitised larvae and feeding incidences between channels. Common t-tests were utilised to compare environmental conditions, mean standard lengths, and mean natural log-transformed gut fullness between channels. Paired $t$-tests were employed for the comparison between infection status, depths of capture, and size classes in each channel. Bootstrapping was performed to determine (1) the standard error of $R$, (2) standard errors of $C_{24}$, and (3) to compare 2 values of $C_{24}$ (Crowley 1992). To calculate the standard error of $R$, we first randomly withdrew, with replacement, values from the original gut fullness $(F)$ data obtained at each of the 2 consecutive sampling periods used to estimate $R$. These values were used to compute 1 simulated value of evacuation rate following Eq. (3). This procedure was executed 5000 times (Manly 1991), and the standard deviation of these simulated values was the bootstrap estimate of the standard error of $R$ (Efron \& Tibshirani 1991). Similarly, to calculate standard errors of $C_{24}, 5000$ simulated values of $C_{24}$ were calculated with Eq. (1) using one of the preceding simulated values of $R$ (without replacement) and values of $F$ randomly selected with replacement from the original gut fullness data collected at each sampling period. Finally, to compare $C_{24}$ between groups, a distribution of $5000 D^{\prime}$ values was generated at the same time as the calculation of standard errors of $C_{24}$

$$
D^{\prime}=\left(C_{24(A)}^{\prime}-C_{24(B)}^{\prime}\right)-D_{\text {obs }}
$$


where $C_{24(A)}^{\prime}$ and $C_{24(B)}^{\prime}$ were the simulated daily ingestion rate of Groups $A$ and $B$, and $D_{\text {obs }}$ was the observed difference between the 2 original daily ingestion rates. Two daily ingestion rates were significantly different when the observed difference $\left(D_{\text {obs }}\right)$ was outside the central $95 \%$ values of the generated distribution of $D^{\prime}$ (Manly 1991).

\section{RESULTS}

\section{Laboratory experiment}

Mean back-calculated lengths at the beginning of the experiment ranged from 7.04 to $7.19 \mathrm{~mm}$ and did not vary significantly among treatments (turbidity: $F_{1,8}$ $=3.18$ and $\mathrm{p}=0.11$; food density: $F_{3,8}=2.37$ and $\mathrm{p}=$ 0.15 i interaction: $F_{3,8}=3.50$ and $p=0.07$ ). Mean absolute growth rates during the study ranged from 0.142 to $0.226 \mathrm{~mm} \mathrm{~d}^{-1}$ (Fig. 2) and varied significantly among turbidity treatments $\left(F_{1.8}=15.42, \mathrm{p}=0.004\right)$, and among food density treatments $\left(F_{3,8}=37.42, \mathrm{p}<\right.$ $0.0001)$. The interaction was not significant $\left(F_{3,8}=0.46\right.$, $\mathrm{p}=0.72$ ). Pairwise comparisons indicated that fastergrowing larvae are associated with higher turbidities and higher food densities (Fig, 2). The turbidity advantage represented a $14.4 \%$ increase of the growth component in the energy budget.

Mean total ingestion estimates during the $12 \mathrm{~d}$ experiment ranged from 137.9 to $350.2 \mu \mathrm{g}$ dry $1100 \mu \mathrm{g}$ dry] ${ }^{-1}$ (Fig. 2) and varied significantly among food density treatments $\left(F_{3,8}=2285.71, \mathrm{p}<0.0001\right)$, but not among turbidity treatments $\left(F_{1,8}=0.11, \mathrm{p}=0.75\right)$. The interaction was not significant $\left(F_{3,8}=2.57, \mathrm{p}=0.13\right)$. Pairwise comparisons indicated that total ingestion increased with food density as did growth rate, but there was no increasing ingestion with turbidity to account for the $14.4 \%$ augmentation in growth. Mortality of smelt larvae was lower in the high food density treatments and in the high turbidity treatment (Fig. 2), but mean mortality rates varied significantly only among food density treatments (food density: $F_{3,8}=$ 37.11 and $p<0.0001$; turbidity: $F_{1.8}=1.68$ and $p=0.23$; interaction: $F_{3,8}=0.13$ and $p=0.94$ ).
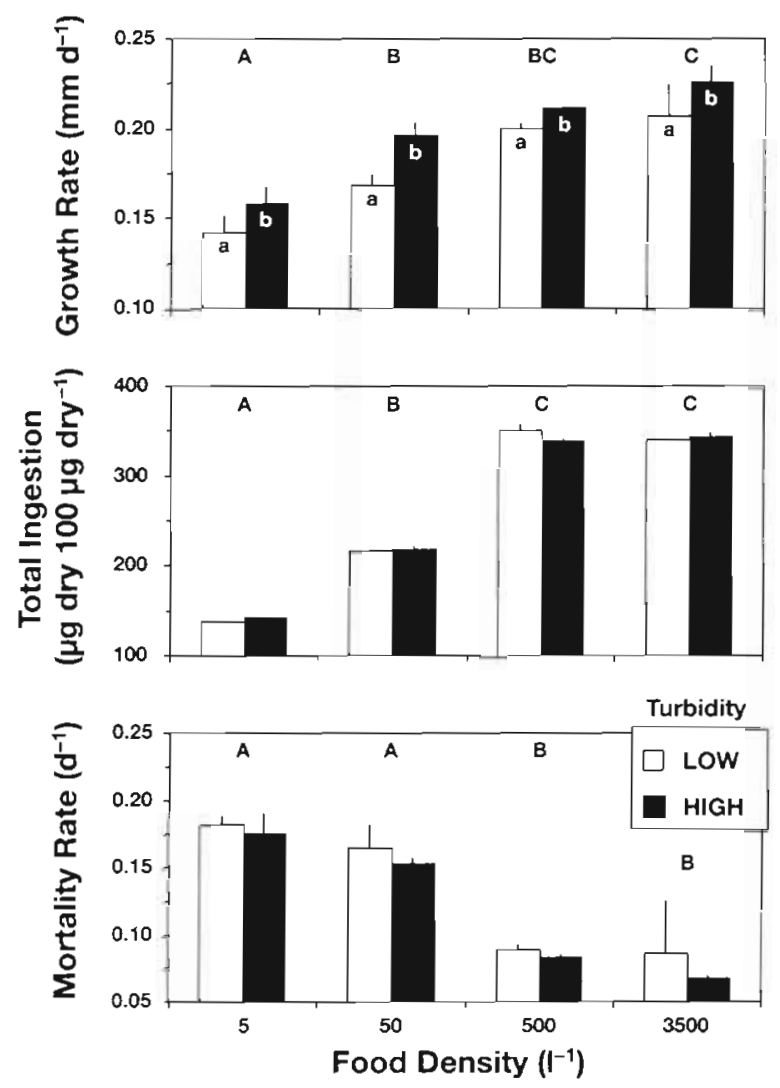

Fig. 2. Mean growth rate (+SD), mean total ingestion (+SD) and mean mortality rate $(+S D)$ in each treatment representing a combination of 4 levels of food density and 2 levels of turbidity. Dissimilar capital letters above bars indicate a significant difference between food density levels. Dissimilar lower case letters above bars indicate a significant difference between turbidity levels. Statistical differences between turbidity levels are the same at each food density level because the interaction is not significant

\section{Field survey}

Food density and temperature were not significantly different between the Middle Channel and the Northern Channel, while salinity and turbidity varied significantly (Table 2). However, the difference in salinity seemed not to be biologically important, especially for an estuarine fish. Mean turbidity fluctuated from 10 to

Table 2. Comparison of environmental conditions in the Middle Channel (sampled on 22 to 24 July 1996) and in the Northern Channel (sampled on 29 to 31 July 1996) in the St. Lawrence ETM

\begin{tabular}{|c|c|c|c|c|c|c|c|}
\hline \multirow[t]{2}{*}{ Variable } & \multicolumn{3}{|c|}{ Middle Channel } & \multicolumn{3}{|c|}{ Northern Channel } & \multirow[t]{2}{*}{$p$} \\
\hline & Mean & $\mathrm{SD}$ & $\mathrm{n}$ & Mean & $\mathrm{SD}$ & $\mathrm{n}$ & \\
\hline Food density (number $\mathrm{l}^{-1}$ ) & 66.14 & 29.92 & 4 & 50.74 & 24.14 & 4 & 0.4538 \\
\hline Temperature $\left({ }^{\circ} \mathrm{C}\right)$ & 19.97 & 0.33 & 16 & 20.21 & 0.91 & 17 & 0.3445 \\
\hline Salinity (psu) & 0.17 & 0.09 & 16 & 1.11 & 1.07 & 17 & 0.001 .4 \\
\hline Turbiclity (NTU) & 21.25 & 9.57 & 16 & 50.44 & 9.16 & 17 & $<0.0001$ \\
\hline
\end{tabular}




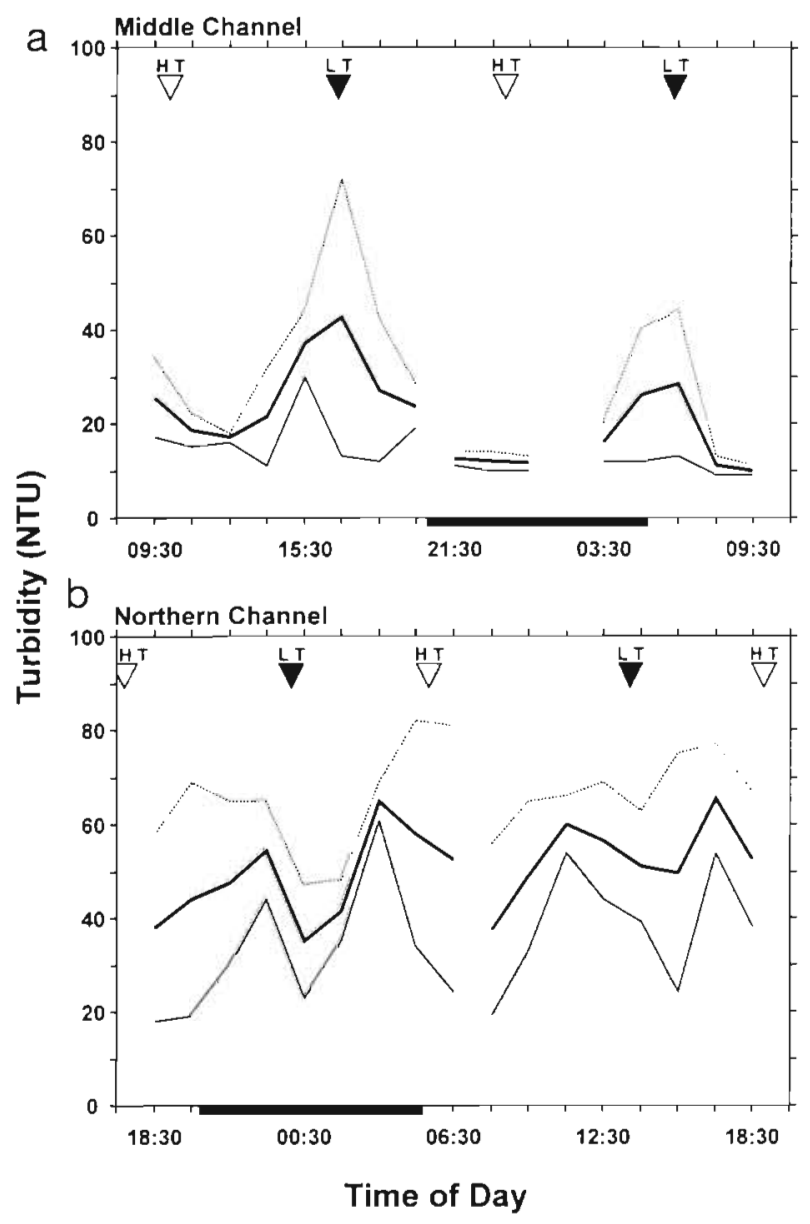

Fig. 3. Temporal variability of mean turbidity (-), surface turbidity $(-)$, and bottom turbidity $(\cdots .$.$) in the Middle$ Channel (a) and in the Northern Channel (b). Dark horizontal bars on the $x$-axis indicate night time, $H T=$ high tide, $L T=$ low tide. $x$-axis does not match between panels

43 NTU in the Middle Channel, and from 35 to 66 NTU in the Northern Channel (Fig. 3).

The examination of the 905 digestive tract contents of smelt larvae collected in the St. Lawrence ETM revealed a diet of low diversity based principally on the copepod Eurytemora affinis, and the cladoceran Bosmina longirostris (Table 1). Prey items larger than $1 \mathrm{~mm}$ in length such as Gammarus, Daphnia, Mysid and Diptera were observed in the gut of 84 smelt larvae measuring $25.0 \mathrm{~mm}$ on average and not smaller than $19.9 \mathrm{~mm}$. The presence of at least 1 parasite was noted within the intestine of 343 larvae. In most cases ( 340 guts), the parasite was a cestode of the genus Protocephalus. The 3 remaining guts contained an unidentified trematode. For the subsequent analysis, smelt larvae infected by the trematode were pooled with the larvae infected by the cestode to form the parasitised larvae. Except for prey fragments, few other organic particles were found in the intestine.
Examination of the temporal variations in the gut fullness of larvae showed that the feeding rhythm was associated with the tidal cycle and the photoperiod (Fig. 4). In both channels, gut fullness increased during periods of coincidence between daylight and flooding tide, but decreased during periods of ebb tide or darkness. Mean standard length was significantly lower for larvae collected in the Middle Channel than for larvae caught in the Northern Channel (Table 3). This difference is largely attributable to the $7 \mathrm{~d}$ of growth separating the 2 sampling periods. The proportion of larvae with food in their gut (feeding incidence) was significantly lower in the Middle Channel than in the Northern Channel. However, both channels exhibited high levels of feeding incidence (Table 3). Mean gut fullness estimates varied from 0.53 to $5.29 \mu \mathrm{g}$ dry $[100 \mu \mathrm{g}$ dry $]^{-1}$ in the Middle Channel, and from 0.81 to $6.61 \mathrm{\mu g}$ dry $[100 \mu \mathrm{g} \mathrm{dry}]^{-1}$ in the Northern Channel (Fig. 4) and were not significantly different between channels $\left(t_{31}=\right.$ $0.187, \mathrm{p}=0.853$ ). Evacuation rate was estimated to be

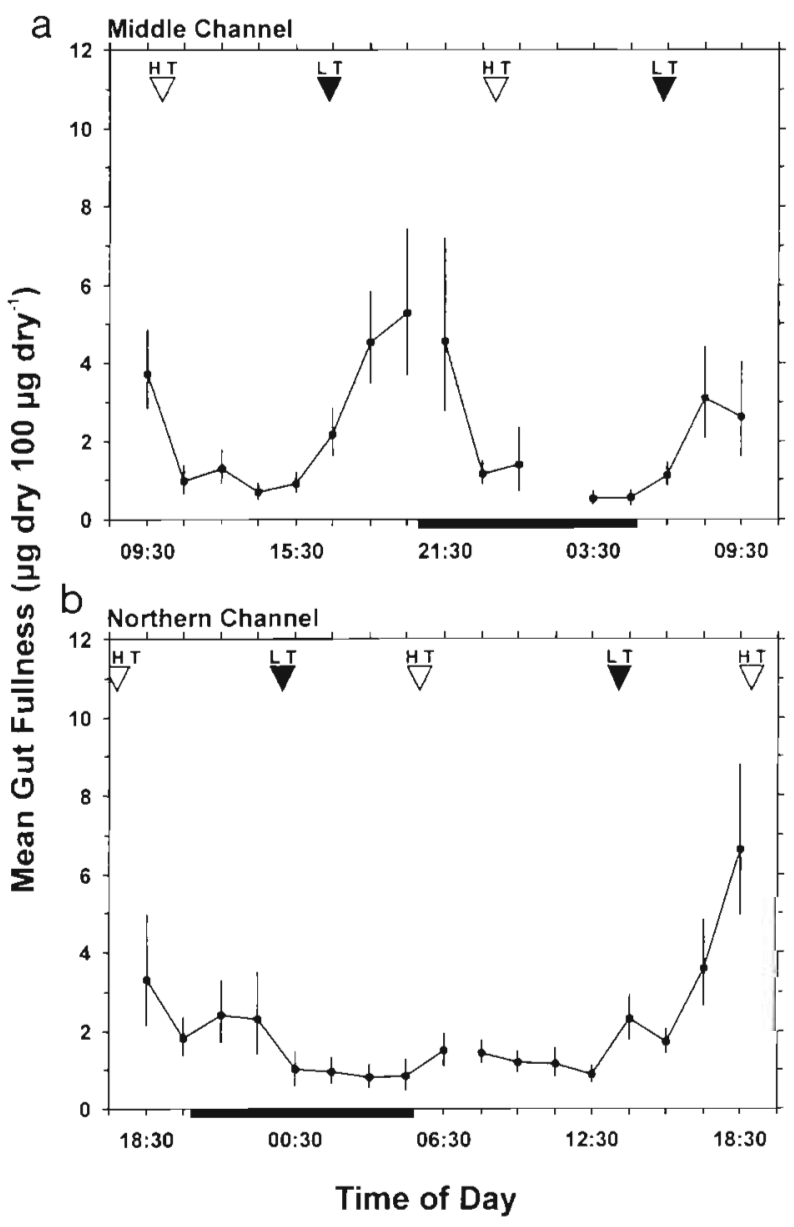

Fig. 4. Temporal variability of the mean gut fullness of smelt larvae in the Middle Channel (a) and in the Northern Channel (b). Vertical lines represent $95 \% \mathrm{CI}$, dark horizontal bars on the $x$-axis indicate night time, HT = high tide, LT = low tide. $x$-axis does not match between panels 
Table 3. Comparison of standard lengths, feeding incidences and daily ingestion rates of smelt larvae between the Middle Channel and the Northern Channel. Numbers in parenthesis are the SD for standard length and the bootstrap estimate of SE for daily ingestion rate

\begin{tabular}{|lccc|}
\hline & Middle Channel & Northern Channel & $p$ \\
\hline Standard length $(\mathrm{mm})$ & $19.49(3.09)$ & $21.32(3.89)$ & $<0.0001$ \\
Feeding incidence $(\%)$ & 87.61 & 91.90 & 0.033 \\
Daily ingestion rate & $29.22(6.60)$ & $30.67(6.01)$ & 0.436 \\
( $\mathrm{kg}$ dry $\left.100 \mu \mathrm{g} d r \mathrm{y}^{-1} \mathrm{~d}^{-1}\right)$ & & & \\
\hline
\end{tabular}

Parasites were observed in 34 and $41 \%$ of the guts analysed in the Middle Channel and in the Northern Channel respectively. This difference was significant $\left(\chi^{2}=4.963, p=0.026\right)$. Mean gut fullness estimates were compared between parasitised and non-parasitised larvae (Fig. 5), and were significantly lower for parasitised larvae in the Middle Channel $\left(t_{15}=5.23, \mathrm{p}<0.0001\right)$ and in the Northern Channel $\left(t_{16}=6.29\right.$, $\mathrm{p}<0.0001$ ). Also, standard length, feeding incidence, and daily ingestion rates of infected larvae were significantly lower than those of noninfected larvae in the 2 channels (Table 4 ).

Mean gut fullness estimates were lower for larvae collected in the bottom layer (Fig. 6) and for small larvae (Fig. 7) in the Middle Channel (depth, $t_{14}=2.92$,

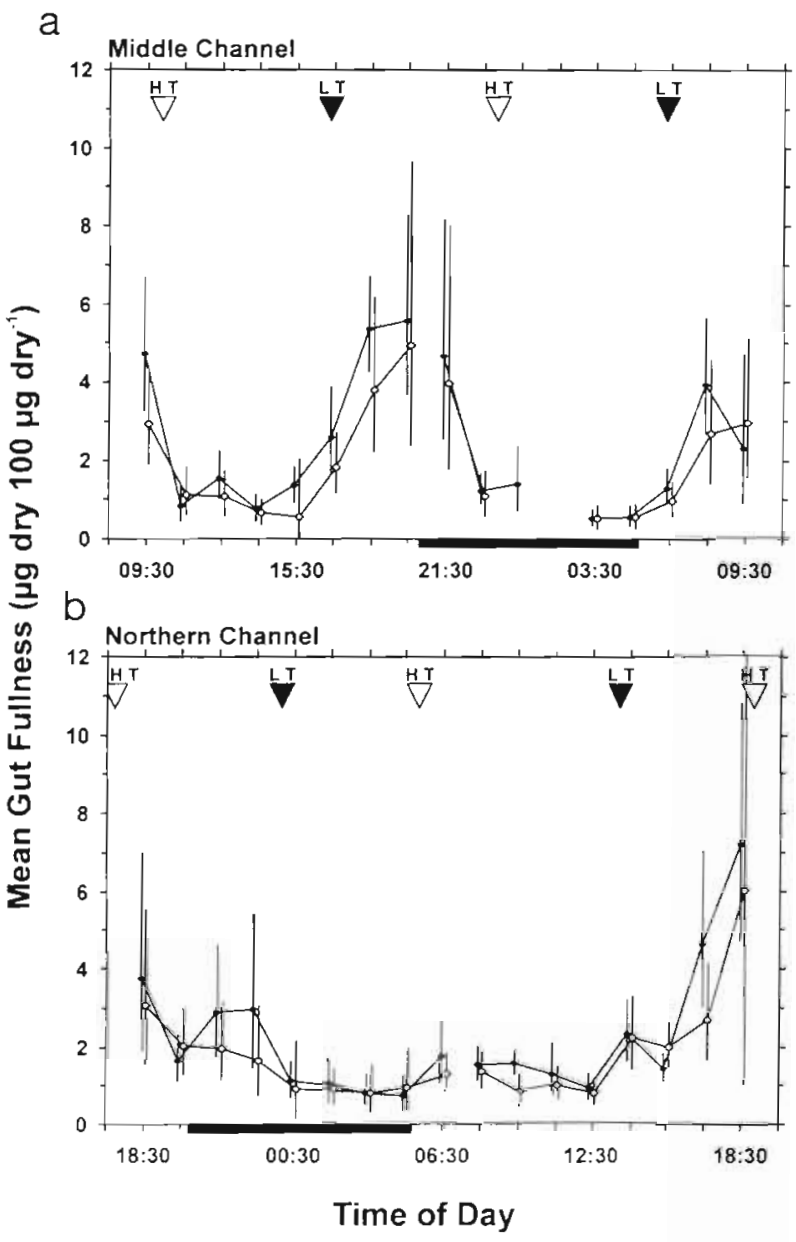

Fig. 6. Temporal variability of the mean gut fullness of smelt larvae collected in the surface layer $(\bullet)$ and in the bottom layer (o) in the Middle Channel (a) and in the Northern Channel (b). Vertical lines represent $95 \%$ CI, dark horizontal bars on the $\mathrm{X}$-axis indicate night time, $\mathrm{HT}=$ high tide, $\mathrm{LT}=$ low tide. $x$-axis does not match between panels
Fig. 5. Temporal variability of the mean gut fullness of para. sitised $(\bullet)$ and non-parasitised smelt larvae $(0)$ in the Middle Channel (a) and in the Northern Channel (b). Vertical lines represent $95 \% \mathrm{Cl}$, dark horizontal bars on the $x$-axis indicate night time, $H T=$ high tide, $L T=$ low tide. $x$-axis does not match

night time, $H T=$ high tide, $L T=$ low tide
between panels
0.631 ( $\mathrm{SE}=0.130$ ), which corresponded to the slope of the decrease in the natural log-transformed mean gut nificant difference in daily ingestion rates between the 2 channels (Table 3 ).

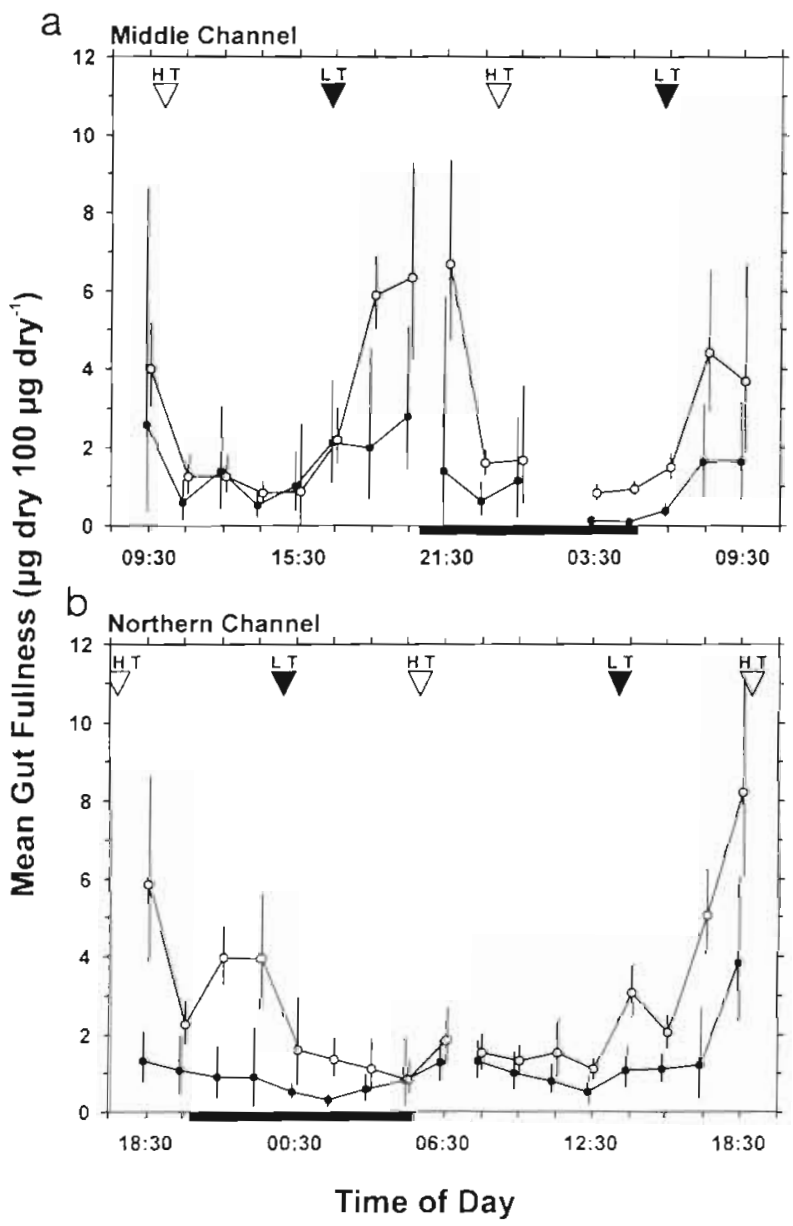


Table 4. Comparison of standard lengths, feeding incidences and daily ingestion rates of parasitised and non-parasitised smelt larvae in the Middle Channel and the Northern Channel. Numbers in parenthesis are the SD for standard length and the bootstrap estimates of SE for daily ingestion rates

\begin{tabular}{|c|c|c|c|}
\hline & Infected larvae & Non-infected larvae & $\mathrm{p}$ \\
\hline \multicolumn{4}{|l|}{ Middle Channel } \\
\hline Standard length (mm) & $18.12(2.69)$ & $20.21(3.05)$ & 0.0006 \\
\hline Feeding incidence $(\%)$ & 74.50 & 94.43 & $<0.0001$ \\
\hline $\begin{array}{l}\text { Daily ingestion rate } \\
\left(\mu \mathrm{g} d r y 100 \mu g \mathrm{dry}^{-1} \mathrm{~d}^{-1}\right)\end{array}$ & $16.39(4.21)$ & $38.61(8.45)$ & 0.009 \\
\hline \multicolumn{4}{|l|}{ Northern Channel } \\
\hline Standard length $(\mathrm{mm})$ & $20.28(3.47)$ & $22.05(3.99)$ & $<0.0001$ \\
\hline Feeding incidence $(\%)$ & 86.08 & 96.00 & $<0.0001$ \\
\hline $\begin{array}{l}\text { Daily ingestion rate } \\
\left(\mu \mathrm{g} \text { dry } 100 \mu \mathrm{g} \mathrm{dry}^{-1} \mathrm{~d}^{-1}\right)\end{array}$ & $17.91(3.60)$ & $39.96(8.22)$ & 0.005 \\
\hline
\end{tabular}

$\mathrm{p}=0.011_{i}$ size, $\left.t_{\mathrm{i5}}=5.77, \mathrm{p}<0.0001\right)$ and in the Northern Channel (depth, $t_{16}$ $=2.67, \mathrm{p}=0.017 ;$ size, $t_{16}=8.96, \mathrm{p}<$ $0.0001)$. Feeding incidence was also significantly lower for larvae caught in the bottom layer (Table 5) and for small larvae (Table 6). However, bootstrap analysis indicated no significant difference in daily ingestion rates between the surface larvae and the bottom larvae in the 2 channels (Table 5). Daily ingestion rates were significantly higher for large larvae in both channels (Table 6). Further experiments are needed to test the interaction between fish size and parasites.

\section{DISCUSSION}

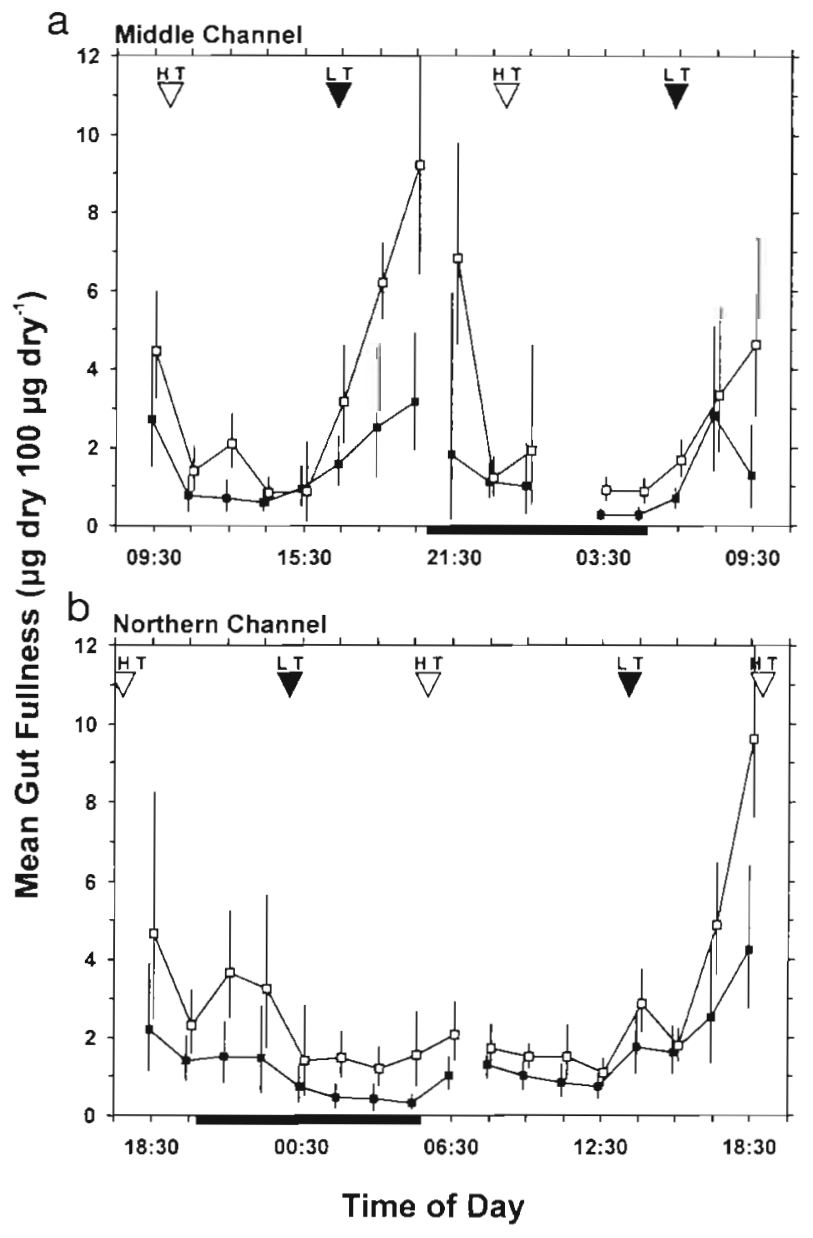

Fig. 7. Temporal variability of the mean gut fullness of small (-) and large smelt larvae (a) in the Middle Channel (a) and in the Northern Channel (b). Vertical lines represent $95 \%$ CI, dark horizontal bars on the $x$-axis indicate night time, $\mathrm{HT}=$ high tide, LT $=$ low tide. $x$-axis does not match between panels

\section{Energetic consequences of feeding in a turbid estuarine environment}

The laboratory experiment showed that an increase in turbidity significantly enhanced the growth rate of smelt larvae. Higher growth rates were also observed in striped bass larvae raised in turbid water ( $>40$ NTU) in comparison with individuals kept in clear water (Chesney 1989). Furthermore, an increase in food density up to 500 organisms $1^{-1}$ also resulted in better larval growth, an effect demonstrated in many laboratory studies (e.g. Wyatt 1972, Werner \& Blaxter 1980, Houde \& Schekter 1981, Kiørboe \& Munk 1986). No evidence was found in the laboratory that ingestion increased to account for greater growth in higher turbidities. The lack of a relationship between turbidity and feeding is corroborated by direct estimation of ingestion rates in the low-turbidity Middle Channel and in the high-turbidity Northern Channel of the St. Lawrence ETM. All together, these results suggest that at a constant food level, larvae ingest similar rations but grow more in higher turbidities. Thus, from an energetic perspective, an increase in turbidity appears to have the effect of reducing energy expenses.

Energy budgets are mass-balanced equations in which the energy ingested by fish is partitioned into distinct physiological compartments such as standard metabolism, heat increment, egestion, excretion, stress, activity and growth (Brett \& Groves 1979). Two components are more likely to be affected by an increase in turbidity: the activity and the stress components. Activity has been demonstrated to be a substantial and variable part of the energy budget of juvenile fish (Boisclair \& Sirois 1993, Madon \& Culver 1993). Moreover, due to the metabolic uniqueness of larval 
Table 5. Comparison of standard lengths, feeding incidences, and daily ingestion rates of smelt larvae captured in the surface layer and in the bottom layer of the Middle Channel and the Northern Channel. Numbers in parenthesis are the SD for standard length and the bootstrap estimates of SE for daily ingestion rates

\begin{tabular}{|c|c|c|c|}
\hline & Surface larvae & Bottom larvae & $\mathrm{p}$ \\
\hline \multicolumn{4}{|l|}{ Middle Channel } \\
\hline Standard length (mm) & $19.53(3.33)$ & $19.46(2.80)$ & 0.689 \\
\hline Feeding incidence $(\%)$ & 91.38 & 83.33 & 0.011 \\
\hline $\begin{array}{l}\text { Daily ingestion rate } \\
\left(\mu \mathrm{g} \text { dry } 100 \mu \mathrm{gry}^{-1} \mathrm{~d}^{-1}\right)\end{array}$ & $31.28(7.45)$ & $26.57(6.02)$ & 0.676 \\
\hline \multicolumn{4}{|l|}{ Northern Channel } \\
\hline Standard length (mm) & $21.42(3.71)$ & $21.22(4.04)$ & 0.348 \\
\hline Feeding incidence $(\%)$ & 95.32 & 88.46 & 0.007 \\
\hline $\begin{array}{l}\text { Daily ingestion rate } \\
\left(\mu g \text { dry } 100 \mu g d^{-1} \mathrm{~d}^{-1}\right)\end{array}$ & $33.98(6.98)$ & $27.57(5.73)$ & 0.764 \\
\hline
\end{tabular}

Table 6. Comparison of feeding incidences, and daily ingestion rates of small and large smelt larvae in the Middle Channel and the Northern Channel. Numbers in parenthesis are the bootstrap estimates of SE for daily ingestion rates

\begin{tabular}{|c|c|c|c|}
\hline & Small larvae & Large larvae & $\mathrm{p}$ \\
\hline \multicolumn{4}{|l|}{ Middle Channel } \\
\hline Feeding incidence (\%) & 78.44 & 96.79 & $<0.0001$ \\
\hline $\begin{array}{l}\text { Daily ingestion rate } \\
\left(\mu \mathrm{g} \text { dry } 100 \mu \mathrm{g} \mathrm{dry}^{-1} \mathrm{~d}^{-1}\right)\end{array}$ & $18.08(4.52)$ & $43.93(9.56)$ & 0.006 \\
\hline \multicolumn{4}{|l|}{ Northern Channel } \\
\hline Feeding incidence $(\%)$ & 85.47 & 98.30 & $<0.0001$ \\
\hline $\begin{array}{l}\text { Daily ingestion rate } \\
\left(\mu \mathrm{g} \text { dry } 100 \mu \mathrm{g} \mathrm{dry}^{-1} \mathrm{~d}^{-1}\right)\end{array}$ & $21.29(4.40)$ & $42.33(8.23)$ & 0.011 \\
\hline
\end{tabular}

review by Dower et al. 1997). Some of the aforementioned studies on turbidity have been conducted in the absence of turbulence or with very low levels of turbulence, as is the case in experimental chambers or lake enclosures. In such cases, an increase in turbidity may reduce the encounter rate due to a reduction in the visibility of the prey. In the presence of turbulence however, turbiaity may not reduce the encounter rate. For instance, in estuarine environments, the high level of turbidity is closely related to the high level of mixing of the water column. An increase in turbidity may be associated with an increase in turbulence. Thus the encounter rate may not be affected.

The lower energetic costs incurred by larvae in higher turbidities may have many implications for smelt exploiting a turbid estuarine environment. Lower turbidity levels contribute to the poor growth of smelt larvae found downstream of the ETM (Sirois \& Dodson unpubl.). Within the ETM, larvae experience highly variable levels of turbidity on both the horizontal and the vertical axis during the growing season. However, on average, turbidity is high and consequently may provide an energetic advantage. For fish larvae of species

fish that exhibit high specific growth rates, the energy available over and above the basic requirements may be insufficient to simultaneously support high rates of growth and of swimming activity (Wieser et al. 1988). Therefore, if turbidity reduces larval fish activity, more energy is available for growth.

Little is known of the importance and the variability of stress in fish energy budgets. This component is probably included in the standard metabolism expenses due to the difficulty in isolating and estimating it. An increase in turbidity may diminish larval stress due to factors such as reduction of predation risk (Bruton 1985).

The diversity of results obtained among studies concerning the influence of turbidity on feeding rate may be related to encounter rate. Rothschild \& Osborn (1988) introduced the hypothesis that encounter rates between planktonic predators and their prey are largely governed by microscale turbulence. Following Rothschild \& Osborn (1988), many reports have documented the influence of microscale turbulence on encounter and ingestion rates of fish larvae and have formed the foundations of the 'turbulence theory' (see that are not adapted to such variations in turbidity levels, we suggest that the results may not be equally applicable. Similarly, the outcome of an artificial increase in turbidity may produce effects that differ from those observed in this study.

\section{Feeding rhythm}

The field survey allowed the documentation of the feeding rhythm of larval rainbow smelt in natural conditions. Firstly, smelt larvae fed during daylight hours as do many other fish larvae (e.g. Young \& Davis 1990, Anderson 1994). Secondly, they fed during flooding tide when they actively migrate to the surface layer to achieve retention in the ETM (Laprise \& Dodson 1989a). Flooding tide also corresponds to the period of greatest mixing of the water column (Laprise \& Dodson 1989a). Therefore the feeding window of smelt larvae occurred when there was a coincidence of daylight and flooding tide. Variations in photoperiod and tidal cycle generate feeding windows ranging from ca 5 to $9 \mathrm{~h} \mathrm{~d}^{-1}$ during the growing season in the St. Lawrence 
ETM. This may substantially influence the daily ingestion rate and survival of first-feeding larvae (Sirois \& Dodson unpubl.).

The suggestion that larval smelt fed principally in the surface layer is also supported in this study by the higher biomasses of prey found in the gut and the higher feeding incidence of larvae sampled in the 0 to $5 \mathrm{~m}$ layer. However, it was not supported by the estimates of daily ingestion rate at both depths. These results were difficult to interpret because it was not possible to know if larvae captured in the bottom layer were not feeding in the surface layer a few minutes before sampling.

Dauvin \& Dodson (1990) observed that feeding incidences of larval smelt in the St. Lawrence ETM were maximal at low tide, declining to minimal values during high tide. Three elements may explain the apparent contradiction with our results. First, their analysis was based on 2 series of sampling that included 7 flooding tide periods. Among these, 3 coincided with night time where the decline is consistent with our results. Second, their sampling was executed at a fixed anchor station that collected larval smelt from the downstream region at high tide, and larvae from the upstream area at low tide. Smelt larvae in the upstream part of the St. Lawrence Estuary are larger, exhibit better growth, experience higher food densities, and ingest more food than larvae found downstream (Dodson et al. 1989, Laprise \& Dodson 1989b, Laprise 1991, Sirois \& Dodson unpubl.). Third, feeding incidence is only a rough estimate of ingestion rate because it does not take into account the quantity of food consumed. Therefore, results presented by Dauvin \& Dodson (1990) do not contradict the conclusion of the present study. The sampling design used in the present study provides a clearer rendition of feeding rhythms exhibited by smelt larvae in the St. Lawrence ETM and point out the complexity of potential interactions between larvae and environment that can affect ingestion.

\section{Influence of parasites}

This study clearly demonstrated the direct impact of parasites on the feeding of smelt larvae. Parasitised larvae ingested half of the food consumed by nonparasitised larvae. This result is consistent with observations of cestode-infected herring larvae in the North Sea (Heath \& Nicoll 1991). Three mechanisms can explain the reduction of ingestion. Firstly, Heath \& Nicoll (1991) suggested that parasites enhance the evacuation rate by consuming a proportion of the digestive tract content. Secondly, parasites affect the condition (Yamashita 1979) and behaviour (Rosenthal
1967) of larval fish which may diminish foraging activity. Thirdly, parasitised larvae may physically not be able to ingest more food because of the lack of space in the gut. Examination of gut content in this study revealed that the number and size of the cestode parasites were variable and could occupy up to $60 \%$ of the space in the digestive tract.

The decrease in feeding due to parasitism was associated with a reduced growth rate as illustrated by the lower standard lengths observed in infected larvae. Moreover, the size advantage of non-infected larvae is expected to be amplified because larger larvae ingest proportionally more food than smaller larvae. Hence, in the St. Lawrence Estuary, parasitism may be a major factor in the determination of year-class strength of rainbow smelt because survival of larvae is strongly related to growth (Sirois \& Dodson unpubl.).

Our knowledge of the ecology of the cestode parasite observed in the digestive tract content of smelt larvae is very limited. Description of the life cycle, developmental rate, spatial distribution, and temporal variations in abundance of this parasite would allow one to quantify and, subsequently, predict its impact on the survival of smelt larvae. Many scientists claim that parasitism is an underestimated regulator of animal populations (May 1983, Minchella \& Scott 1991). The observations presented here support this view. The impact of parasitism on larval survival and subsequent recruitment in fishes may merit far more attention than afforded to date.

Acknowledgements. We particularly thank François Caron, Roger $O$. Picard and Serge Tremblay of the Ministère de l'Environnement et de la Faune, Quebec government for their collaboration with their research boat, 'Vladykov', for our field survey, and Guy Trencia for supplying smelt eggs. We also thank Marie-Josée Abgrall, Jean-Yves Anctil, Marie Lagacée and Frédéric Lecomte for their valuable help in the field and in the laboratory, and Dr David J Marcogliese for the identification of the cestode. Dr Louis Bernatchez, Dr Louis Fortier, Dr Pierre Pepin and 3 anonymous referees provided valuable comments on an earlier version of this manuscript. This project was supported by grants from NSERC (Canada) to J.J.D. P.S. was funded by NSERC (Canada), FCAR (Quebec) and GIROQ fellowships.

\section{LITERATURE CITED}

Able KW (1978) Ichthyoplankton of the St. Lawrence estuary: composition, distribution, and abundance. J Fish Res Board Can 35:1518-1531

Anderson JT (1988) A review of size-dependent survival during pre-recruit stages of fishes in relation to recruitment. $J$ Northwest Atl Fish Sci 8:55-66

Anderson JT (1994) Feeding ecology and condition of larval and pelagic juvenile redfish Sebastes spp. Mar Ecol Prog Ser 104:211-226

Bailey KM, Houde ED (1989) Predation on eggs and larvae and the recruitment problem. Adv Mar Biol 25:1-83 
Bernatchez L, Martin S (1996) Mitochondrial DNA diversity in anadromous rainbow smelt, Osmerus mordax Mitchill: a genetic assessment of the member-vagrant hypothesis. Can J Fish Aquat Sci 53:424-433

Boehlert GW, Morgan JB (1985) Turbidity enhances feeding abilities of larval Pacific herring, Clupea harengus pallasi. Hydrobiologia 123:161-170

Boisclair D. Leggett WC (1985) Rate of food exploitation by littoral fishes in a mesotrophic north-temperate lake. Can J Fish Aquat Sci 42:556-566

Boisclair D. Marchand F (1993) The guts to estimate fish daily ration. Can J Fish Aquat Sci 50:1969-1975

Boisclair D, Sirois P (1993) Testing assumptions of fish bioenergetics models by direct estimation of growth, consumption, and activity rates. Trans Am Fish Soc 122: $784-796$

Bottrell HH, Duncan A, Gliwicz ZM, Grygierek E, Herzig A, Hillbricht-Ilkowska A, Kurasawa $\mathrm{H}$, Larsson P, Weglenska $T$ (1976) A review of some problems in zooplankton production studies. Norw J Zool 24:419-456

Breitburg D (1988) Effects of turbidity on prey consumption by striped bass larvae. Trans Am Fish Soc 117:72-77

Brett JR, Groves TDD (1979) Physiological energetics. In: Hoar WS, Randall DJ, Brett JR (eds) Fish physiology. VIIr Academic Press, New York, p 279-352

Bristow BT, Summerfelt RC (1994) Performance of larval walleye cultured intensively in clear and turbid water. J World Aquacult Soc 25:454-464

Bristow BT, Summerfelt RC, Clayton RD (1996) Comparative performance of intensively cultured larval walleye in clear, turbid, and coloured water. Prog Fish Cult 58:1-10

Bruton NM (1985) The effects of suspensoids on fish. Hydrobiologia 125:221-241

Burkill PH, Kendall TF (1982) Production of the copepod Eurytemora affinis in the Bristol Channel. Mar Ecol Prog Ser 7:21-31

Campana SE, Jones CM (1992) Analysis of otolith microstructure data. In: Stevenson DK, Campana SE (eds) Otolith microstructure examination and analysis. Can Spec Publ Fish Aquat Sci 117:73-100

Chesney EJ Jr (1989) Estimating the food requirements of striped bass larvae Morone saxatilis: effects of light, turbidity and turbulence. Mar Ecol Prog Ser 53:191-200

Chigbu P, Sibley TH (1996) Biometrical relationships, energy content and biochemical composition of Neomysis mercedis from Lake Washington. Hydrobiologia 337:145-150

Courtois R, Dodson JJ (1986) Régime alimentaire et principaux facteurs influençant l'alimentation des larves de capelan (Mallotus villosus), d'éperlan (Osmerus mordax) et de hareng (Clupea harengus harengus) dans un estuaire partiellement mélangé. Can $J$ Fish Aquat Sci 43 968-979

Crowley PH (1992) Resampling methods for computationintensive data analysis in ecology and evolution. Annu Rev Ecol Syst 23:405-447

Culver DA, Boucherle MM, Bean DJ, Fletcher JW (1985) Biomass of freshwater crustacean zooplankton from lengthweight regressions. Can J Fish Aquat Sci 42:1380-1390

Cushing DH (1975) Marine ecology and fisheries. University Press, Cambridge

Cushing DH (1990) Plankton production and year-class strength in fish population: an update of the match/mismatch hypothesis. Adv Mar Biol 26:249-293

Dauvin JC, Dodson IJ (1990) Relationship between feeding incidence and vertical and longitudinal distribution of rainbow smelt larvae (Osmerus mordax) in a turbid wellmixed estuary. Mar Ecol Prog Ser 60:1-12
Dodson JJ, Dauvin JC, Ingram RG, D'Anglejan B (1989) Abundance of larval rainbow smelt (Osmerus mordax) in relation to the maximum turbidity zone and associated macroplanktonic fauna of the middle St. Lawrence Estuary. Estuaries 12:66-81

Dower JF, Miller TJ, Leggett WC (1997) The role of microscale turbulence in the feeding ecology of larval fish. Adv Mar Biol 31:169-220

Dumont HJ, Van de Velde I, Dumont S (1975) The dry weight estimate of biomass in a selection of Cladocera, Copepoda and Rotifera from the plankton, periphyton and benthos of continental waters. Oecologia 19:75-97

Efron B, Tibshirani R (1991) Statistical data analysis in the computer age. Science 253:390-395

Elliott JM, Persson L (1978) The estimation of daily rates of food consumption for fish. J Anim Ecol 47:977-991

Govoni JJ (1983) Helminth parasitism of three larval fishes in the northern Gulf of Mexico. Fish Bull US 81:895-898

Heath $M$, Nicoll $N$ (1991) Infection of larval herring by helminth parasites in the North Sea and the effect on feeding incidence. Cont Shelf Res 11:1477-1489

Heinle DR, Flemer DA (1975) Carbon requirements of a population of the estuarine copepod Eurytemora affinis. Mar Biol 31:235-247

Héroux D, Magnan P (1996) In situ determination of food daily ration in fish: review and fjeld evaluation. Environ Biol Fishes 46:61-74

Hillbricht-Ilkowska A, Stanczykowska A (1969) The production and standing crop of planktonic larvae of Dreissena polymorpha Pall. in two Mazurian lakes. Pol Arch Hydrobiol 16:193-203

Hjort J (1914) Fluctuations in the great fisheries of northern Europe reviewed in the light of biological research. Rapp P-V Réun Cons Int Explor Mer 20:1-128

Houde ED (1987) Fish early life dynamics and recruitment variability. Am Fish Soc Symp 2:17-29

Houde ED, Schekter RC (1981) Growth rates, rations and cohort consumption of marine fish larvae in relation to prey concentrations. Rapp P-V Réun Cons Int Explor Mer 178 $441-453$

Johnston DD, Wildish DJ (1982) Effect of suspended sediment on feeding by larval herring (Clupea harengus harengus L.). Bull Environ Contam Toxicol 29:261-267

Kiørboe T, Munk P (1986) Feeding and growth of larval herring, Clupea harengus, in relation to density of copepod nauplii. Environ Biol Fishes 17:133-139

Laprise R (1991) La rétention des larves d'éperlan (Osmerus mordax) et de poulamon (Microgadus tomcod) dans le bouchon de turbidité de l'estuaire moyen du Saint-Laurent. PhD thesis, Université Laval, Québec

Laprise R, Dodson JJ (1989a) Ontogeny and importance of tidal vertical migrations in the retention of larval smelt Osmerus mordax in a well-mixed estuary. Mar Ecol Prog Ser 55:101-111

Laprise R, Dodson JJ (1989b) Ontogenic changes in the longitudinal distribution of two species of larval fish in a turbid well-nixed estuary. J Fish Biol 35(Suppl A):39-47

Lasker $\mathrm{R}$ (1978) The relation between oceanographic conditions and larval anchovy food in the California Current identification of factors contributing to recruitment failure Rapp P-V Réun Cons Int Explor Mer 173:212-230

Lebour MV (1918) A trematode larva from Buccinum unda tum and notes on trematodes from post-larval fish. J Mar Biol Assoc UK 11:514-517

MacKenzie BR, Leggett WC, Pelers RH (1990) Estimating larval fish ingestion rates: can laboratory derived values be reliably extrapolated to the wild? Mar Ecol Prog Ser 67:209-225 
MacKenzie K (1974) Immature digeneans from the alimentary tract of larval and juvenile pelagic stages of haddock, Melanogrammus aeglefinus (L.). J Fish Biol 6:103-106

Madon SP, Culver DA (1993) Bioenergetics model for larval and juvenile walleyes: an in situ approach with experimental ponds. Trans Am Fish Soc 122:797-813

Malmqvist B, Brönmark C (1981) Filter feeding in larval Lampetra planeri: effect of size, temperature and particle concentration. Oikos 38:40-46

Manly BFJ (1991) Randomization and Monte Carlo methods in biology. Chapman \& Hall, London

Marak RR (1974) Food and feeding of larval redfish in the Gulf of Maine. In: Blaxter JHS (ed) The early life history of fish. Springer-Verlag, New York p 267-275

Mauchline $J$ (1998) The biology of calanoid copepods. Adv Mar Biol 33:1-710

May RM (1983) Parasitic infections as regulators of animal populations. Am Sci 71:36-45

Miller TJ, Crowder LB, Rice JA, Marschall EA (1988) Larval size and recruitment mechanisms in fishes: toward a conceptual framework. Can J Fish Aquat Sci 45:1657-1670

Minchella DJ, Scott ME (1991) Parasitisrn: a cryptic determinant of animal community structure. Trends Ecol Evol 6: $250-253$

Miner JG, Stein RA (1993) Interactive influence of turbidity and light on larval bluegill (Lepomis macrochirus) foraging. Can J Fish Aquat Sci 50:781-788

Pigeon D, Dodson JJ, Bernatchez L (1998) A mtDNA analysis of spatiotemporal distribution of two sympatric larval populations of rainbow smelt (Osmerus mordax) in the St. Lawrence River estuary, Quebec, Canada. Can J Fish Aquat Sci 55:1739-1747

Pöckl M (1992) Effects of temperature, age and body size on moulting and growth in the freshwater amphipods Gammarus fossarum and G. roeseli. Freshw Biol 27:211-225

Richards SW, Riley GA (1967) The benthic epifauna of Long

Editorial responsibility: Otto Kinne (Editor),

Oldendorf/Luhe, Germany
Island Sound. Bull Bingham Oceanogr Collect Yale Univ 19:89-135

Rosenthal H (1967) Parasites in larvae of herring (Clupea harengus) fed with wild plankton. Mar Biol 1:10-15

Rothschild BJ, Osborn TR (1988) Small-scale turbulence and plankton contact rates. J Plankton Res 10:465-474

Sirois P, Lecomte F, Dodson JJ (1998) An otolith-based backcalculation method to account for time-varying growth rate in rainbow smelt (Osmerus mordax) larvae. Can J Fish Aquat Sci 55:2662-2671

Smock LA (1980) Relationships between body size and biomass of aquatic insects. Freshw Biol 10:375-383

Sprung $M$ (1993) The other life: an account of present knowledge of the larval phase of Dreissena polymorpha. In: Nalepa T, Schloesser D (eds) Zebra mussels: biology, impacts, and control. Lewis Publishers, Ann Arbor, MI, p 39-54

Swenson WA, Matson ML (1976) Influence of turbidity on survival, growth, and distribution of larval lake herring (Coregonus artedii). Trans Am Fish Soc 105:541-545

Werner RG, Blaxter JHS (1980) Growth and survival of herring (Clupea harengus) in relation to prey density. Can J Fish Aquat Sci 37:1063-1069

Wieser W, Forstner H, Medgyesy N, Hinterleitner S (1988) To switch or not to switch: partitioning of energy between growth and activity in larval cyprinids (Cyprinidae: Teleostei). Funct Ecol 2:499-507

Wyatt T (1972) Some effects of food density on the growth and behaviour of plaice larvae. Mar Biol 14:210-216

Yamashita K (1979) Damages of red seabream (Pagulus major) larvae caused by the parasitism of larval digenetic trematode. Fish Pathol 14:39-42

Young JW, Davis TLO (1990) Feeding ecology of larvae of southern bluefin, albacore and skipjack tunas (Pisces: Scombridae) in the eastern Indian Ocean. Mar Ecol Prog Ser 61:17-29

Submitted: February 5, 1999; Accepted: August 8, 1999 Proofs received from author(s): February 7, 2000 